\title{
Diàleg socràtic a la classe de ciències
}

\author{
Joan Aliberas \\ IES Josep Puig i Cadafalch, Mataró \\ jalibera@xtec.cat
}

A classe utilitzem habitualment el diàleg amb l'alumnat com un dels mètodes habituals d'ensenyament. Aplicant-hi algunes tècniques pot esdevenir encara més útil.

\section{Diàleg entre maneres de mirar}

Cada ciència proporciona una manera pròpia de mirar el món; una manera que sol ser força diferent de com els nostres alumnes solen mirar-lo.

Ensenyar-los ciència és, en bona mesura, ajudar-los a madurar les seves pròpies maneres de veure les coses. Llavors poden utilitzar-les per realitzar inferències vàlides sobre el comportament del món i així intervenir-hi amb eficàcia.

Quan professor i alumne es reconeixen capacitat per fer inferències sobre la realitat, i volen parlar-ne, el diàleg pot ser molt fructífer. Com és sabut, en el diàleg socràtic (o mètode maièutic) el mestre fa preguntes al deixeble, conduint-lo a conclusions vàlides.

En ciències és molt útil anar conduint de forma conscient aquest intercanvi d'arguments vers determinades fites. Així, comprendre un sistema o fenomen, sol demanar una sèrie de passos (Izquierdo $i$ Aliberas, 2004):

- Establir quins són els components del sistema que tenen un paper rellevant en els seu funcionament.

- Determinar quines de les propietats d'aquests components resulten rellevants per donar compte del seu comportament.

- Interrelacionar el funcionament de tots aquests components per arribar a explicar el comportament real del sistema.

- Establir i respectar algunes regles d'utilització dels components, de les propietats i del llenguatge per referir-s'hi.

La utilització del diàleg socràtic pretén ser una alternativa a l'explicació magistral tradicional, intentant afavorir la participació activa de cada alumne en la marxa de la classe, sobretot per ajudar-lo a construir i posar en funcionament representacions mentals dinàmiques (models) progressivament més satisfactòries i científiques.

\section{Començant a parlar de l'àtom}

El següent diàleg, amb característiques socràtiques, va tenir lloc a quart d'ESO. Es tractava de començar l'estudi de l'àtom.

La seva durada real és d'uns quinze minuts. Es tractava d'explorar quines idees tenien els alumnes sobre l'àtom i anar introduint les concepcions científiques.

Les intervencions del professor estan indicades amb la lletra $P$. Les de l'alumne que és a la pissarra, i principal interlocutor, amb la lletra A. I les dels diversos alumnes que intervenen en el debat des de la seva taula, amb la lletra B.

En les intervencions, els noms respectius els representarem per $P, A$ i $B$, en cursiva. Entre parèntesis $i$ en cursiva hi ha alguns comentaris que constitueixen una descripció d'accions, o bé l'anàlisi de la situació que en fa el professor a fi de preparar la següent acció o rèplica.

(El professor ha fet sortir un alumne a la pissarra. Sap que altres anys ja han estudiat l'àtom per sobre; a més, segur que molts n'hauran vist dibuixats. Ara passarà a explorar el concepte que té de l'àtom l'alumne de la pissarra, per veure fins a on es pot arribar).

$P$. Segurament que deus haver sentit a parlar dels àtoms, oi?

A. Sí...

(La resposta és dubitativa, insegura. $P$ suposa que reflecteix la inseguretat sobre els seus conei- 
xements sobre àtoms. Provarà de fer-li explicitar el que en sap).

A. Sabries dibuixar-ne un?

(A dibuixa un puntet a la pissarra).

$P$. Això vol dir que l'àtom és molt petit, oi? Tothom hi deu estar d'acord, no?

(Al grup, ningú no ho contradiu. El professor, que no s'esperava això, vol utilitzar un sistema de representació més útil per als seus propòsits. Un cop ha quedat assumit per accident que els àtoms són petits, tractarà de passar a discutir l'estructura de l'àtom).

P. Com que volem entendre com funciona un àtom necessitem un dibuix gros, per veure de què està fet. $A$ veure (adreçant-se a $A$ ) si ens dibuixes com està fet un àtom...

(A Dibuixa una rodona d'un pam de diàmetre. Per al $P$ és insuficient per encabir-hi els components).

P. Més gran, sense por...

(Ara la dibuixa molt més gran).

P. Bé... L'àtom és tot d'una peça, o té parts que el formen?

(A dibuixa una rodona més petita al mig. Com que no diu res, $P$ mira de fer-li explicitar).

$P$. Què és, això? (Referint-se a la rodona petita).

A. El nucli...

(De moment s'està en bon camí per aclarir les parts que té el sistema, però convé donar-hi noms).

P. El nucli, d'acord. I el que queda fora del nucli, té algun nom?

(L'alumne de la pissarra queda indecís).

B. És l'escorça.

P. Sí senyor, es diu escorça! (Adreçant-se de nou a $A$ ): Apuntes aquests dos noms en el seu lloc al dibuix?

(A ho fa. Aquí es produeix un episodi, que no reproduïm, que comença amb uns comentaris de $P$ respecte de la mida relativa de l'àtom i del nucli $i$ acaba posant un exemple per ajudar a l'alumnat a fer-se càrrec de la gran desproporció entre un $i$ altre, que no es pot reflectir en el dibuix de la pissarra).

(Després d'això, $P$ necessita un nivell de representació més detallat per als raonaments que vol fer més endavant. Per això s'ha de penetrar més endins en l'estructura de l'àtom, ha de fer explicitar els components dels elements que ara té representats a la pissarra).

P. A veure, A... Com t'imagines l'escorça...? De què està feta...?

(A ha quedat rumiant, el professor gira la vista al grup, interrogant amb la mirada).

B. D'electrons.

A. Sí, d'electrons.

P. Sabries dibuixar-los?

(A dibuixa diverses rodones molt petites, repartides per la zona de l'escorça).

$P$. Els electrons estan repartits per...
A. ...per l'escorça...

\section{Completant el model d'escorça}

(Ara $P$ intentarà completar els components $i$ la seva distribució).

$P$. Molt bé. I en el nucli, què hi ha?

A. Neutrons.

P. D'acord. Hi ha alguna cosa més...?

B. Plu... plutons...

P. Protons, amb erra, protons... (S'adreça a $A$ ). Com ho dibuixes, perquè vegem les diferències...?

(A dibuixa boles de dos colors a dins del nucli. Un cop completada la topologia, $P$ vol fer explicitar les propietats o atributs rellevants per comprendre el funcionament del sistema).

$P$. Totes aquestes boles que has dibuixat, totes aquestes partícules, tenen càrrega elèctrica 0 no? Els electrons...?

A. (Dubtant) ...són positius...

B. No, són negatius.

A. Sí senyora, els electrons són negatius, (s'adreça a $A$ ) ho recordes...? Dibuixes la càrrega negativa dels electrons? Cada electró, un negatiu... (A ho va dibuixant). Així...

$P$. I en el nucli, també hi ha càrregues?

A. Els neutrons són neutres...

$P$. No tenen càrrega... I els protons què deuen ser?

A. Positius.

P. D'acord, dibuixem unes quantes partícules del nucli com a protons i els altres seran neutrons...

(A va posant signes a les partícules que n'han de tenir. $P$ aprofita per fer un resum, assenyalant al dibuix i mirant al grup).

$P$. Molt bé. En resum, si mirem les càrregues elèctriques de l'àtom... on és que hi ha les càrregues negatives?

(La tàctica de $P$, pròpia del diàleg socràtic, és evitar al màxim les afirmacions. Les substitueix per preguntes que sap que, tot $i$ semblar fàcils, no ho són per a molts dels alumnes. De totes formes, evita de fer preguntes que els alumnes puguin percebre com a trivials o prou sabudes, excepte quan el que busca és resumir, reunint informació que havia anat quedant dispersa; tasca que tampoc no és trivial. Es tracta que els alumnes participin en el discurs $i$ se'l facin seu. Les preguntes que fa serveixen d'exemple a l'alumnat com a preguntes a fer-se en un diàleg interior quan es tracti de pensar sobre un sistema semblant. A més, les respostes que va rebent li serveixen al professor per monitoritzar el procés i poder-lo regular).

B. A fora...

P. ...? (Posa cara d'estranyat).

B. A l'escorça!

$P$. A la part de més enfora, que en diem escorça, allà és on hi ha les càrregues negatives, a tot 
aquest tros... (ho assenyala). I és negativa a causa dels...

B. ...dels electrons!

P. Exacte, tots aquests electrons negatius... En canvi, la càrrega positiva és a...

B. En els protons!

$P$. En el nucli, en els protons que hi al nucli és on hi ha la càrrega positiva... Tenim, doncs, (assenyala l'escorça a la pissarra, mirant a $A$ ) que tota aquesta zona té càrrega...

A. (insegur)...negativa...

P. Sí, sí, negativa... mentre que en el nucli la càrrega és...

A. Positiva.

P. Positiva, d'acord.

(Ara $P$ veu el moment d'abordar la part dinàmica de la representació de l'àtom. Continua assenyalant amb les mans l'escorça i el nucli).

$P$. Però, a veure, rumiem una cosa que passa aquí... Tots aquests electrons (assenyala l'escorça) són negatius... es fan força entre ells?

A. Sí... de repulsió...

$P$. Per tant, què haurien de fer, tots aquests electrons?

B. Haurien de marxar...

$P$. Tantes càrregues negatives s'han de repel-lir i els electrons haurien de marxar... O no? Negatiu contra negatiu...

A. ...Però també hi han els positius del nucli, que els atrauen.

B. Clar, llavors no poden marxar...

$P$. Doncs sí: els electrons, tots negatius, es repel-leixen, però els protons, el nucli positiu, els reté. Hi esteu d'acord...?

( $P$ ha culminat la construcció del model. Ara crearà diferents situacions per posar-lo en funcionament i poder fer inferències).

P. A veure... (s'adreça a $A$ ) què passaria amb els electrons, si de cop i volta desaparegués el nucli?

A. Marxarien.

$P$. I per què no marxen quan hi ha el nucli?

A. Perquè s'atrauen.

(La inferència és correcta, la representació mental que $A$ s'ha fet funciona bé).

\section{Una comparació per consolidar el model}

P. Els electrons es queden al voltant del nucli perquè són negatius, i estan atrets pel nucli, que és positiu. D'acord? Passa una cosa semblant amb els planetes. Per què la Terra va donant voltes al Sol en comptes de perdre's per l'espai?

( $P$ treu ara la comparació amb els planetes per fer més normal aquesta idea de l'atracció. Vol fer una comparació amb un fenomen amb trets sem- blants. Amb cada mà fa una bola, una la fa girar a l'entorn de l'altra).

B. Perquè el Sol ens atrau...

$P$. I si desaparegués el Sol de cop i volta, què farien els planetes?

$(P$ repeteix la inferència amb un sistema estructuralment semblant).

B. Marxarien...

P. Marxarien, es dispersarien, cadascun aniria per la seva banda, ja no haurien de girar entorn de res. Però si els planetes no marxen és perquè els atrau...

A. El Sol...

$P$. I els electrons no marxen de l'àtom perquè...

A. El nucli els atrau.

P. Els atrau, el nucli els atrau. És l'atracció entre càrregues positives i negatives. D'acord?

\section{Construint una representació mental dinàmica del nucli}

(Ara $P$ mirarà de construir un model semblant per al nucli. Comença pels seus components).

$P$. Molt bé. Fixem-nos ara en el nucli. Què hi tenim, en el nucli (adreçant-se a $A$ )?

A. Protons i neutrons.

( $P$ passa a explicitar les propietats que li convé destacar).

$P$. Els protons eren positius i els neutrons, no tenen càrrega, diem que són neutres, sense càrrega... Oi que és això (mirant al grup)?

B. (Assenteixen alguns alumnes. $P$ aborda la part dinàmica).

$P$. Doncs a veure, no hi veieu una cosa estranya, aquí...? Aquí tenim el nucli (l'assenyala al dibuix), amb protons i neutrons. Hi ha uns quants protons positius en un espai molt petit, molt petit, el del nucli. Creus que es deuen fer força aquests protons (adreçant-se a A)?

A. Sí.

P. Com?

A. Es deuen fer repulsió... Perquè tots són positius.

P. Tants positius i tan junts, es deuen fer una força de repulsió enorme! És això?

A. (Assenteix amb el cap).

P. ...i per tant, deuen sortir tots disparats del nucli, no...? ...i ja no tenim nucli...!

(El funcionament de la representació no es correspon amb la realitat. Es veuen cares d'interrogant entre l'alumnat. $P$ ha d'introduir la modificació que torni satisfactori el model).

P. No... En realitat sabem que això no és així. Qui deu ser que atrau els protons més fort encara perquè no s'escapin? (No contesten). Qui pot ser? Qui més hi ha, aquí en aquesta pel-lícula...?

A. Els electrons. 
P. Els electrons. (P no s'ho esperava). Quina força fan els electrons contra els protons?

A. S'atreuen.

P. I cap a on atreuen als protons?

B. Cap enfora!

P. Cap enfora. Això ajuda a mantenir junts els protons?

A. No..., faran que marxin del nucli...

( $P$ ha aconseguit fer descartar una possible solució que sap que no és correcta. Ha fet que els mateixos alumnes ho infereixin).

P. Els electrons farien que els protons marxessin del nucli... Llavors, per què s'hi queden? Qui els reté?

(Un cop descartats uns components, els electrons, com a causants d'aquesta força que dóna estabilitat al nucli, $P$ espera que es fixin en altres components).

B. El neutrons?

P. Exacte, els neutrons. Els protons, tots positius i molt propers es repel.leixen amb una força fortíssima... (Fa gestos). Però els neutrons els retenen amb una força molt més gran encara... A veure, no és una força elèctrica, perquè els neutrons no tenen càrrega, eh? Entre protons i neutrons hi ha una força e-nor-me que els manté junts, però que només es nota a distàncies molt petites, tan petites com el nucli d'un àtom. Com que nosaltres no estem acostumats a aquestes distàncies tan petites, no l'hem notada mai, aquesta força... Però és una força que existeix, que és molt poderosa, i que manté units els nuclis dels àtoms... Si ara mateix deixés d'existir, aquesta força, què passaria...?

\section{Fent inferències}

( $P$ estableix un context per posar en marxa el model i posar-lo a prova).

B. El nucli es desfaria.

(La inferència ha estat correcta, el model mental funciona... si més no el de B).

P. És clar: sense neutrons els nuclis es desmuntarien. I què passaria amb l'escorça dels àtoms? Els electrons quedarien al seu lloc?

B. No.

$P$. No, perquè quan haguessin marxat els protons... què passaria amb els electrons...?

B. ...també marxarien.

(La inferència és correcta, el model segueix funcionant bé).

P. Marxarien, ja no hi hauria ningú que els aguantés allà. Per tant, doncs, què hauria passat amb els àtoms, si no hi hagués aquella força del nucli?

A. Que es desmuntarien.

$P$. Els àtoms es desmuntarien $i$ deixarien d'existir. I nosaltres de què estem fets? D'àtoms, no? Sí o no...? Sí, sí, $B$, estem fets d'àtoms, com tota classe de matèria (s'ha adreçat a un alumne amb expressió de dubte). Doncs si no existís aquella força del nucli, que es diu interacció forta, nosaltres tampoc no existiríem. És un descans saber que és molt forta i que per aquest costat no cal que patim...

El diàleg continua després relacionant aquesta lluita de forces en el nucli amb l'energia nuclear i la seva utilització en la bomba atòmica i les centrals nuclears.

La introducció de l'estructura de l'àtom es completa amb la idea que l'àtom és neutre i que això imposa la igualtat -en principi- del nombre de protons amb el d'electrons.

També es donaven dades sobre les masses de les tres partícules. Això feia possible una nova comparació amb els planetes per ajudar a entendre què es colloca al centre (el cos de més massa) i què queda al seu entorn.

Després de fer un resum oral de tot plegat es passava a fer-ne l'aplicació analitzant un fenomen d'electricitat estàtica i un circuit elèctric mitjançant el model científic d'àtom que s'acabava de construir.

Per acabar d'assimilar el model es va demanar que cada alumne elaborés un text expositiu sobre el que s'havia discutit. Es preparà primer un esquema a la pissarra que l'endemà va fer servir com a pauta de correcció.

\section{El diàleg}

El diàleg anteriorment transcrit mostra el procés de convertir uns continguts previs més o menys assumits, però que normalment resten inerts, en uns altres més madurs, més dinàmics, doncs permeten la realització d'inferències.

Cal dir que el diàleg més freqüent a classe no és de reflexió teòrica com en aquest cas, sinó la interpretació d'experiments o fets mitjançant teories.

La utilització del diàleg socràtic és especialment útil per generar un clima de classe participatiu, com a recurs de monitorització i regulació del procés d'aprenentatge de forma continuada, per millorar l'autoestima d'alguns alumnes i la seva implicació en les tasques escolars i, naturalment, per millorar els aprenentatges.

Al final, les classes resulten més vives i interessants, tant per als alumnes com per al professor. Els alumnes acaben descobrint que també ells poden fer inferències científiques i donar i jutjar arguments. El professor s'adona de les dificultats que troba l'alumnat per fer-se seu el nou coneixement $i$ les pot atendre. En un ensenyament més transmissiu, aquestes dificultats passen desapercebudes, encara que hi siguin. 
El diàleg socràtic amb un alumne davant dels altres, contribueix a captar l'atenció dels alumnes, ja que s'identifiquen més fàcilment amb el que el seu company fa per donar resposta a les situacions plantejades pel professor, que no pas amb els raonaments que aquest pugui presentar.

El diàleg, per si sol, no és suficient per garantir l'aprenentatge; però constitueix una eina per obrir un nou camí, que després cal consolidar.

\section{Bibliografia}

Izquierdo, M. i Aliberas, J. (2004). Pensar, actuar $i$ parlar a la classe de ciències. Per un ensenyament de les ciències racional i raonable. Bellaterra: UAB. 